\title{
Phenotypic Characterization of Genetically Distinct Phytophthora cinnamomi Isolates from Avocado
}

\author{
Rodger J. Belisle, Brandon McKee, Wei Hao, Margaret Crowley, Mary Lu Arpaia, \\ Timothy D. Miles, James E. Adaskaveg, and Patricia Manosalva ${ }^{\dagger}$
}

First, second, third, seventh, and eighth authors: Department of Microbiology and Plant Pathology, and fourth and fifth authors: Department of Botany and Plant Sciences, University of California, Riverside, CA 92521; and sixth author: School of Natural Sciences, California State University, Monterey Bay, Seaside 93955.

Accepted for publication 30 July 2018.

\begin{abstract}
Phytophthora cinnamomi, the causal agent of Phytophthora root rot (PRR), is the most destructive disease of avocado worldwide. A previous study identified two genetically distinct clades of A2 mating type avocado isolates in California; however, the phenotypic variation among them was not assessed. This study described the phenotype of a subset of isolates from these groups regarding growth rate, growth temperature, virulence, and fungicide sensitivity. Isolates corresponding to the A2 clade I group exhibited higher mycelial growth rate and sensitivity to higher temperatures than other isolates. Among the fungicides tested, potassium phosphite had the highest 50\% effective concentration for mycelial

growth inhibition and oxathiapiprolin had the lowest. Mycelial growth rate and potassium phosphite sensitivity phenotypes correlate with specific groups of isolates, suggesting that these traits could be a group characteristic. Moreover, isolates that are more virulent in avocado and less sensitive to potassium phosphite were identified. A detached-leaf P. cinnamomi inoculation method using Nicotiana benthamiana was developed and validated, providing an alternative method for assessing the virulence of a large number of isolates. This information will help avocado PRR management and assist breeding programs for the selection of rootstocks resistant against a more diverse pathogen population.
\end{abstract}

The oomycete pathogen Phytophthora cinnamomi Rands, causal agent of Phytophthora root rot (PRR), is the most destructive disease of avocado worldwide (Erwin and Ribeiro 1996). In California, avocado PRR affects 60 to $75 \%$ of avocado growers, who lose approximately $\$ 40$ million annually (Ploetz 2013). This globally distributed oomycete is called "the biological bulldozer" for its capacity to infect over 3,000 plant species, causing devastating impacts in natural ecosystems, forestry, agriculture, and the nursery industry (Hardham 2005; Hardham and Blackman 2018; Kamoun et al. 2015). The economic impact due to $P$. cinnamomi infestation is evident in the forest and food industry, affecting eucalyptus, pine, oak (Zentmyer 1980), and other fruit crops such as pineapple, peach, and highbush blueberry (Shands et al. 2016). Losses include not only decreases in crop yield and product value but also large amounts of money spent annually on control measures. There are no effective means to eradicate $P$. cinnamomi from infested areas because it survives in moist soil or dead plant material as chlamydospores for long periods under adverse conditions (Hardham and Blackman 2018; Reitmann et al. 2017; Zentmyer and Mircetich 1966). Several PRR control strategies have been found to reduce the impact of this invasive pathogen, including the use of chemical treatment (phosphonatebased and mefenoxam), tolerant plants, and management practices (e.g., proper diagnostics, mulching, and proper irrigation).

$P$. cinnamomi is a hemibiotrophic pathogen, feeding initially from living host cells (biotrophic stage) and then switching to necrotrophy

${ }^{\dagger}$ Corresponding author: Patricia Manosalva; E-mail: patricia.manosalva@ucr.edu

Funding: This work was supported by the University of California Riverside Initial Complement Funds, the California Avocado Commission (CAC) (008599-002), and the United States Department of Agriculture Specialty Crop Block Grant Program (USDA-SCBGP) (SCB16057).

*The $\boldsymbol{e}$-Xtra logo stands for "electronic extra" and indicates that one supplementary table and two supplementary figures are published online.

(c) 2019 The American Phytopathological Society by killing the host cells and feeding from the nutrients released by them (necrotrophic phase) (Fawke et al. 2015; Hardham and Blackman 2018; van den Berg et al. 2018). The entry into the plant is achieved by the adhesion of the motile zoospores to the host tissue, encystment, and germ-tube formation. The germ tubes usually grow and penetrate the root surface via appressorium-like swelling structures, after which plant tissue is rapidly colonized (Hardham 2005). During its biotrophic stage, $P$. cinnamomi projects haustoria into the plant cells for the acquisition of nutrients and release of pathogen proteins (effectors) to aid the infection process in the host (Hardham and Blackman 2018; Huisman et al. 2015; Redondo et al. 2015; van den Berg et al. 2018). This is followed by a necrotrophic stage characterized by host cell death, hyphal proliferation, and production of numerous sporangia (Evangelisti et al. 2017; Hardham 2005; Huisman et al. 2015). Currently, the molecular and genetic basis of $P$. cinnamomi pathogenicity, virulence, and plant immunity against this pathogen are largely unknown due to limitations associated with tree crop biology and the lack of tools available for functional studies in tree crops such as avocado (Pliego-Alfaro and Litz 2007). Arabidopsis and lupin have been used as model systems to study P. cinnamomi-plant interactions (Allardyce et al. 2013; Eshraghi et al. 2011; Rookes et al. 2008). The model plant Nicotiana benthamiana (Bombarely et al. 2012) has been widely used to study the pathogenicity and virulence of similar broad-range and root Phytophthora pathogens such as P. capsici (Chen et al. 2013; VegaArreguín et al. 2014), P. palmivora (Evangelisti et al. 2017; Ekchaweng et al. 2017; Goodin et al. 2008), and P. parasitica (Dalio et al. 2018; Robin and Guest 1994). Moreover, several studies using model plants, crops, and tree crops to study pathogenicity, virulence, and fungicide efficacy of PRR pathogens such as $P$. sojae, $P$. capsici, $P$. parasitica, $P$. palmivora, $P$. cinnamomi, and $P$. ramorum have been done using detached-leaf assays (Denman et al. 2005; Dong et al. 2015; Ekchaweng et al. 2017; Eshraghi et al. 2011; Helliwell et al. 2016; Robin and Guest 1994; Vega-Arreguín et al. 2014).

Phosphite is the most widely used chemical control method for managing PRR caused by several Phytophthora spp., including 
P. cinnamomi (Dobrowolski et al. 2008; Ma and McLeod 2014). Phosphorous acid dissociates to form the phosphonate ion $\left(\mathrm{HPO}_{3}^{2-}\right)$, also called phosphite. Phosphorous acid and its ionized compounds are often referred to as phosphonate or phosphonite. The specific mode of action of phosphite is largely unknown; however, it appears to involve both a direct and an indirect effect on the pathogen (Eshraghi et al. 2014a; Guest and Grant 1991; McGrath 2004). Several studies have assessed the in vitro sensitivity of $P$. cinnamomi to phosphite using mycelial radial growth inhibition in solid and liquid media to identify sensitive and tolerant isolates (Dobrowolski et al. 2008; Fenn and Coffey 1984; Ma and McLeod 2014; Ouimette and Coffey 1989). In California, avocado growers heavily rely on the use of phosphite products to control $P$. cinnamomi; however, the phosphite sensitivity of California avocado isolates is largely unknown.

In addition to phosphite, phenylamide fungicides such as metalaxyl and mefenoxam are also used for managing diseases caused by oomycetes, including P. cinnamomi (Benson and Grand 2000; Erwin and Ribeiro 1996; Hu et al. 2010; Schwinn and Staub 1995). Resistance to metalaxyl has developed in P. capsici, $P$. infestans, and P. nicotianae (Lamour and Hausbeck 2001; Schwinn and Staub 1995; Shew 1985). Phenylamides usually do not inhibit germination of sporangia or encysted zoospores as effectively as they do mycelial growth (Staub and Young 1980). Consequently, inhibition of mycelial growth in vitro has been used as the primary method of determining the sensitivity to these fungicides among isolates of Phytophthora spp. (Benson and Grand 2000; Coffey and Bower 1984). The need for new oomycete-targeted fungicides to control diseases caused by these pathogens, especially those that have developed resistance to phenylamide fungicides, has resulted in the development of several new chemicals with varying modes of action such as fluopicolide (Presidio; Valent Walnut Creek, CA) and oxathiapiprolin (Orondis, Syngenta Crop Protection, Greensboro, NC). Fluopicolide is a pyridinylmethyl-benzamide (acylpicolide) fungicide that disrupts cell division and mitosis by acting on spectrin-like proteins (Briggs et al. 2006). This fungicide is effective to control diseases caused by $P$. capsici (Keinath and Kousik 2011) and P. infestans (Saville et al. 2015). Oxathiapiprolin is the first of the new piperidinyl thiazole isoxazoline class fungicides discovered and developed by DuPont Co. in 2007. The molecular target of oxathiapiprolin is the oxysterol-binding protein (Andreassi et al. 2013). This new fungicide exhibits strong inhibitory activity against a range of agriculturally important plant-pathogenic oomycetes, including $P$. capsici, $P$. infestans, $P$. sojae, Peronospora belbahrii, and Pythium ultimun (Miao et al. 2016; Pasteris et al. 2016; Patel et al. 2015). However, its inhibitory activity against Phytophthora cinnamomi has not been tested.

$P$. cinnamomi is a heterothallic species that requires the presence of both A1 and A2 mating types to undergo sexual reproduction. Despite the fact that both mating types are pathogenic (Kamoun et al. 2015), avocado PRR disease in California is mainly associated with A2 mating type isolates (Pagliaccia et al. 2013). Previous $P$. cinnamomi population studies have revealed low levels of genotypic and phenotypic variation (Beaulieu et al. 2017; Dobrowolski et al. 2003; Duan et al. 2008; Eggers et al. 2012; Engelbrecht et al. 2017; Hu et al. 2010; Linde et al. 1997, 1999; López-Herrera and Pérez-Jiménez 1995; Ma and McLeod 2014; Martin and Coffey 2012; Pagliaccia et al. 2013; Zentmyer et al. 1976; Zentmyer 1980) among isolates from different mating types, origin, isolation source, and host plants; however, only a few were conducted or have included isolates from avocado (Engelbrecht et al. 2017; Linde et al. 1999; López-Herrera and Pérez-Jiménez 1995; Ma and McLeod 2014; Martin and Coffey 2012; Pagliaccia et al. 2013; Zentmyer 1976; Zentmyer 1980). These studies described the existence of three clonal lineages for P. cinnamomi, one corresponding to the A1 mating type isolates and two different clonal lineages for the A2 mating type isolates (A2 type 1 and A2 type 2) (Dobrowolski et al. 2003; Eggers et al. 2012). Pagliaccia et al. (2013) conducted the first study to assess the genetic diversity of $P$. cinnamomi isolates from avocado in California and also found two genetically distinct clades of A2 mating type isolates (A 2 clade I and clade II). The A 2 clade II consisted of isolates with unique genotypes collected only in Southern California. Interestingly, the authors in this study included isolates from $P$. cinnamomi previously identified as belonging to the A2 type 1 and A2 type 2 described by Dobrowolski et al. (2003); however, these isolates clustered within the A2 clade I group, suggesting that the A 2 clade II group identified by Pagliaccia et al. (2013) in California could be another clonal lineage.

No studies have been conducted to assess the phenotype of avocado isolates corresponding to these genetically distinct A2 groups identified in California by Pagliaccia et al. (2013); therefore, the objectives of this study were to (i) assess the phenotype of several avocado isolates corresponding to these A2 clades regarding in vitro mycelial growth rate, optimal growth temperature, virulence, and sensitivity to potassium phosphite and mefenoxam; (ii) test the sensitivity of avocado isolates to fluopicolide and oxathiapiprolin as alternative chemistries for controlling avocado PRR in California; and (iii) develop and validate a detached-leaf assay inoculation method using $N$. benthamiana to circumvent the difficulties associated with the avocado whole-plant root inoculation method to assess the virulence of $P$. cinnamomi isolates. This information will help to design appropriate measures for managing avocado PRR in California and implement efficient and reliable screening methods toward the selection and development of new $P$. cinnamomi-resistant avocado rootstocks effective against a more diverse pathogen population.

\section{MATERIALS AND METHODS}

P. cinnamomi isolates. In total, $12 P$. cinnamomi isolates associated with avocado PRR were used in this study, including 6 isolates from Northern California corresponding to the A2 clade I group, 4 isolates corresponding to the unique A2 clade II subpopulation from Southern California, and 2 isolates collected from the same Southern California region from where the A2 clade II isolates were collected (Supplementary Table S1). A2 clade I isolates from this study represent $5(\mathrm{~N} 2, \mathrm{~N} 3, \mathrm{~N} 4, \mathrm{~N} 6$, and N7) of the 10 total genotypes identified by Pagliaccia et al. (2013). Isolates representing the A2 clade II group covered three (S3, S5, and S6) of the six unique genotypes identified in Southern California. All isolates in this study were obtained from a P. cinnamomi small collection at the University of California Riverside (UCR) Avocado Rootstock Breeding Program. Isolates were maintained as water agar plugs (Boesewinkel 1976). Agar plugs were removed one at the time as needed for each experiment and plated on $10 \%$ clarified V8 agar (cV8A) $\left(10 \mathrm{~g}\right.$ of $\mathrm{CaCO}_{3}$ per 1 liter of $\mathrm{V} 8$ juice spun down at $4,000 \mathrm{rpm}$ for $20 \mathrm{~min}$ ) to resume growth. To ensure that isolates in the collection were free of contamination and avoid any problems with mix samples or inappropriate maintenance of the collection, we sequenced all of the isolates using internal transcribed spacer (ITS) and COX1 spacer regions. Mycelial DNA was extracted using the Qiagen DNeasy plant mini kit (Qiagen, Germantown, MD). Universal primers ITS 1 and ITS4 were used for the ITS region, and primers OOM and FM85 were used for the COX1 spacer region; both sets of primers are described by Kroon et al. (2004). Each 25- $\mu \mathrm{l}$ polymerase chain reaction (PCR) contained $2 \mu \mathrm{l}$ of DNA $(50 \mathrm{ng} / \mu \mathrm{l})$, $2.5 \mu \mathrm{l}$ of $10 \times$ PCR buffer (New England Biolabs, Ipswich, MA), $200 \mu \mathrm{M}$ dNTPs, $0.4 \mu \mathrm{M}$ each primer, and $1.25 \mathrm{U}$ of Taq DNA polymerase (New England Biolabs). PCRs were performed using a Programmed Thermal Controller (PTC-100; MJ Research, Inc., Watertown, MA) with conditions as follows: $95^{\circ} \mathrm{C}$ for $5 \mathrm{~min}$; followed by 35 cycles at $95^{\circ} \mathrm{C}$ for $1 \mathrm{~min}, 50^{\circ} \mathrm{C}$ for $1 \mathrm{~min}$, and $68^{\circ} \mathrm{C}$ for $1 \mathrm{~min}$; and a final extension at $68^{\circ} \mathrm{C}$ for $10 \mathrm{~min}$. PCR products were confirmed on $1 \%$ certified molecular biology agarose gel (Bio-Rad Laboratories, Hercules, CA), stained with ethidium bromide $(0.05 \%$ [vol/vol] $)$, and visualized under UV light using a Universal Hood UV Light Table (75s/00124 with camera model Rs170s; Bio-Rad Laboratories). PCR products were treated with 
Zymo DNA clean and concentrator (Zymo Research Corp, Irvine, CA) according to the manufacturer's instructions to remove excess primers and nucleotides before submitting the samples for Sanger sequencing. DNA sequencing was conducted in both directions with the same primers used for amplification at the UCR Genomics Core facility. Contiguous sequences were generated which were then subjected to a BLASTn search (https://blast.ncbi.nlm.nih.gov/ Blast.cgi) to determine the highest maximum identity to the sequence of the type isolates in GenBank.

Plant material. Two avocado rootstocks were selected based on their $P$. cinnamomi resistance phenotype. Clonal rootstocks corresponding to the moderately resistant Dusa (industry standard) and the susceptible PS.54 (Westfalia Technological Services, Tzaneen, South Africa) were obtained from Brokaw Nursery. The 6-month-old clonally propagated plants were removed from their bags and transplanted into pots after the nurse seed was removed. Plants were grown in a greenhouse with an average maximum temperature range of 25 to $28^{\circ} \mathrm{C}$ at 40 to $50 \%$ relative humidity. Plants were fertilized twice a week and watered every day. $N$. benthamiana seed were germinated in trays and transferred to individual pots 2 weeks postgermination. Plants were grown at $22^{\circ} \mathrm{C}$ with cycles of $16 \mathrm{~h}$ of light and $8 \mathrm{~h}$ of darkness at 40 to $50 \%$ relative humidity.

Effect of temperature and medium on $P$. cinnamomi mycelial growth rate. Temperature is one of the most significant environmental factors affecting growth, reproduction, and pathogenesis of fungi and oomycete pathogens (Zentmyer et al. 1976). The temperatures tested in this study were selected based on the optimal growth temperature range reported for P. cinnamomi (20 to $30^{\circ} \mathrm{C}$ ) (Phillips and Weste 1985; Zentmyer et al. 1976). Mycelial growth rate (millimeters per day) was determined at 22, 25, and $28^{\circ} \mathrm{C}$ on $10 \% \mathrm{cV} 8 \mathrm{~A}$ following the methodology described by Chen and Zentmyer (1970). Mycelial growth rate on $10 \% \mathrm{cV} 8 \mathrm{~A}$ at $22^{\circ} \mathrm{C}$ was also compared with the growth rate on corn meal agar (CMA) (Eckert and Tsao 1962) (Becton Dickinson, Sparks, MD). Agar plugs ( $7 \mathrm{~mm}$ in diameter) were cut from the margin of a 4-day-old colony of $P$. cinnamomi cV8A plates, transferred to their corresponding media plates, and incubated in the dark for 4 days. Colony diameter was measured at 2 and 4 days after plug transfer.

In vitro fungicide sensitivity. The effective concentration of potassium phosphite at which $50 \%$ of the mycelial growth of each isolate was inhibited ( $\mathrm{EC}_{50}$ value) was determined using the traditional agar dilution method as described by Adaskaveg et al. (2015). Potassium phosphite (Prophyt, 34.3\% phosphorous acid; Helena Chemical Co., Collierville, TN) was added to $10 \%$ cV8A to obtain final concentrations of 5, 25, and $100 \mu \mathrm{g} / \mathrm{ml}$. Mycelial agar plugs (6 $\mathrm{mm}$ in diameter) from 6-day-old cultures of $P$. cinnamomi were placed at the center of the plates containing the corresponding chemical concentration. Three replicates were done per each treatment. After incubation for 3 days in the dark at $22^{\circ} \mathrm{C}$, radial colony growth was measured. Colony growth inhibition of each isolate in the presence of potassium phosphite was then calculated as compared with their corresponding control plates without potassium phosphite. This experiment was conducted at least twice. Calculation of the $\mathrm{EC}_{50}$ values for potassium phosphite of each isolate was determined as described by Adaskaveg et al. (2015). Briefly, the $\mathrm{EC}_{50}$ values were determined by fitting regression lines of the natural log-transformed phosphite concentration against the logit-transformed percent inhibition as compared with the control for each isolate. Regression equations were then solved for concentration at 50\% inhibition using Microsoft Excel (version 15.41).

The $\mathrm{EC}_{50}$ values for mefenoxam (Ridomil Gold SL; Syngenta Crop Protection), fluopicolide (Presidio; Valent), and oxathiapiprolin (Orondis; Syngenta Crop Protection), currently used to control diseases caused by oomycete pathogens, were determined using the spiral gradient dilution method described by Förster et al. (2004). Mefenoxam, oxathiapiprolin, and fluopicolide were dissolved in sterile water to make the corresponding stock solutions at 50,5 , and $100 \mu \mathrm{g} / \mathrm{ml}$, respectively. Each fungicide was radially applied to a $15-\mathrm{cm} 10 \% \mathrm{cV} 8 \mathrm{~A}$ plate using a spiral plater (Autoplate 4000; Spiral Biotech, Norwood, MA). Isolates were grown for 7 days in the dark at $22^{\circ} \mathrm{C}$ on $10 \% \mathrm{cV} 8 \mathrm{~A}$ media. Cultures were then cut into strips and placed between sterile hydrophilic cellophane strips ( 5.5 by $0.5 \mathrm{~cm}$ ) (du Pont de Nemours, Wilmington, DE) on new $10 \% \mathrm{cV} 8 \mathrm{~A}$ plates. Plates were incubated for another 7 days in the dark at $22^{\circ} \mathrm{C}$ or until the mycelium had evenly covered the strips. Mycelium-covered cellophane strips were then radially applied across the fungicide concentration gradient on the spiral gradient dilution fungicide plate. The ranges of concentrations used were between 0.0025 to $0.6837 \mu \mathrm{g} / \mathrm{ml}$ (1:274 gradient dilution), 0.0038 to $1.4054 \mu \mathrm{g} / \mathrm{ml}(1: 370)$, and 0.0002 to $0.0572 \mu \mathrm{g} / \mathrm{ml}$ (1:286) for mefenoxam, fluopicolide, and oxathiapiprolin, respectively. For each isolate, duplicated strips were placed at the opposite location on each spiral gradient dilution fungicide plate (two replications). Controls consisted of cV8A plates spirally plated with water, on which cellophane strips were placed as described above. Plates were incubated in the dark at $22^{\circ} \mathrm{C}$. Two independent experiments were conducted. Two days after incubation, the mycelial growth of each isolate in each of the control plates was measured. The location where mycelial growth was inhibited by $50 \%$, compared with growth on the control plates, was determined. The distance between this location and the center of the plate was measured. This distance was used to determine the local fungicide concentration on the agar at the location of $50 \%$ inhibition using the spiral gradient endpoint (SGE) software $\left(\mathrm{EC}_{50}\right.$ value). The $\mathrm{EC}_{50}$ values for each fungicide were calculated using the SGE software (version 1.3; Spiral Biotech) as described by Förster et al. (2004).

Avocado rootstock inoculation. Nine-month-old avocado rootstocks liners were inoculated with $P$. cinnamomi-colonized millet seed. Millet inoculum was prepared according to the method of Drenth and Sendall (2001). Briefly, $175 \mathrm{ml}$ of distilled water was added to $144 \mathrm{~g}$ of millet seed. Excess water was poured off and moistened millet was autoclaved in a $250-\mathrm{ml}$ volumetric flask. Autoclaving was repeated the following day. For each isolate, 10 plugs of $6 \mathrm{~mm}$ in diameter were cut from the margin of a 4-day-old colony of $P$. cinnamomi plate and added to the flask containing the sterilized millet seed. Inoculated millet was incubated in the dark at $25^{\circ} \mathrm{C}$ for 21 days. The millet was then harvested, weighed, and homogenized in a plastic bag. A total of $4.4 \mathrm{~g}$ of inoculum per plant was used for inoculation by placing the inoculated millet around the root collar. Combination isolate inoculum was produced by thoroughly mixing equal amounts of each corresponding isolateinoculated millet seed together. Dusa and PS.54 ungrafted clonal rootstocks were inoculated with individual isolates, a combination of Northern California isolates (North mix), a combination of Southern California isolates (South mix), and a combination of all isolates (All mix). Control plants were treated with uninoculated millet seed that were sterilized and prepared in the same manner as the inoculated millet seed. The experiment was conducted in a greenhouse using a randomized complete block design with five replicates per treatment. The average maximum temperature in the greenhouse was $28^{\circ} \mathrm{C}$, with an average minimum temperature of $14^{\circ} \mathrm{C}$. To confirm that plants were successfully infected, root samples were excised from harvested plants and 10 to 20 segments per plant were surface sterilized in $70 \%$ ethanol and plated onto the PARPH-V8 Phytophthora-selective media (Delvocid pimaricin at $5 \mu \mathrm{g} / \mathrm{ml}$, sodium ampicillin at $250 \mu \mathrm{g} / \mathrm{ml}$, rifamycin at $10 \mu \mathrm{g} / \mathrm{ml}$, Terraclor [pentachloronitrobenzene] at $50 \mu \mathrm{g} / \mathrm{ml}$, and Tachigaren $\left[70 \%\right.$ hymexazol] at $50 \mu \mathrm{g} / \mathrm{ml}$ ). Plates were incubated at $22^{\circ} \mathrm{C}$ for 2 to 3 days in the dark. Phytophthora-infected root pieces were counted on each plate and the presence of $P$. cinnamomi was confirmed based on morphological characteristics. The same procedure was done with the roots of the control plants inoculated with the uninoculated millet, no growth on the roots was observed.

$N$. benthamiana detached-leaf inoculations. Five-week-old $N$. benthamiana were used for detached-leaf inoculations as described by Manosalva et al. (2015), using zoospore suspensions. 
Zoospore suspensions were produced following the protocol described by Londsdale et al. (1988). Briefly, 10 (7-mm) plugs from 6-day-old cultures grown on $10 \% \mathrm{cV} 8$ media were placed on sterile Miracloth (EMD Millipore Corp., Billerica, MA) previously placed on a new $10 \% \mathrm{cV} 8$ plate. Plugs were incubated for 6 days at $22^{\circ} \mathrm{C}$ in the dark; then, the Miracloth was removed from the plate and placed in a flask with $100 \mathrm{ml}$ of cV8 broth. After $20 \mathrm{~h}$ of incubation at $22^{\circ} \mathrm{C}$ in the dark with shaking at $160 \mathrm{rpm}$, the Miracloth was rinsed three times with a salt solution (Londsdale et al. 1988), then incubated for an additional $18 \mathrm{~h}$ at $22^{\circ} \mathrm{C}$ in the dark, with shaking at $160 \mathrm{rpm}$. The Miracloth was then rinsed with $100 \mathrm{ml}$ of $18^{\circ} \mathrm{C}$ water and incubated in $50 \mathrm{ml}$ of $18^{\circ} \mathrm{C}$ water for $1.5 \mathrm{~h}$ to induce zoospore release. The abaxial leaf surfaces of $N$. benthamiana leaves were drop inoculated using $20 \mu \mathrm{l}$ of a zoospore suspension adjusted to $1 \times 10^{4}$ zoospores $/ \mathrm{ml}$ using a hemocytometer (Bright-Line, Horsham, PA.). The inoculated leaves were placed in petri dishes containing $1.5 \%$ water agar and incubated in a precision plant growth incubator (Thermo Scientific, Waltham, MA) under cycles of $18 \mathrm{~h}$ of darkness and $6 \mathrm{~h}$ of light at $25^{\circ} \mathrm{C}$. Lesions were measured at 3 days postinoculation (dpi).

Trypan blue staining. Leaves of $N$. benthamiana were stained at $3,6,12,24,48,72$, and $96 \mathrm{~h}$ postinoculation (hpi) following the protocol described by Manosalva et al. (2015) to assess the progression of $P$. cinnamomi infection. Briefly, leaf tissue was boiled for $5 \mathrm{~min}$ in a 1:1 mixture of ethanol and staining solution (10 ml of lactic acid, $10 \mathrm{ml}$ of glycerol, $10 \mathrm{ml}$ of phenol, and $10 \mathrm{mg}$ of trypan blue dissolved in $10 \mathrm{ml}$ of Milli Q water). Leaf samples were mounted using 50\% glycerol ( $\mathrm{vol} / \mathrm{vol})$ and imaged using a Keyence BZ-X700 fluorescence microscope (Keyence Corporation, Itasca, IL).

$P$. cinnamomi DNA quantification using TaqMan realtime PCR in planta. Four leaf discs $(10 \mathrm{~mm})$ excised from the inoculated area of $N$. benthamiana leaves at all the time points indicated above were used for genomic DNA extractions using a modified $2 \%$ cetyltrimethylammonium bromide (Acros Organics, Fair Lawn, NJ) protocol (Brunner et al. 2001). P. cinnamomi DNA was quantified using the TaqMan real-time PCR protocol described by Miles et al. (2017). For the atp9-nad9 marker system used in this study, PhyG_ATP9_2FTail (5'-AATAAATCATAACCTTCTTTAC AACAAGAATTAATG-3'), PhyG-R6_Tail (5'-AATAAATCAT AAATACATAATTCATTTTTATA-3'), and "Bandaid" primer (5'AATAAATCATAAATACATAATTCRTTTTTRTA-3') served as amplification primers and a cox primer set FMPI2b (5'-GCGTGG ACCTGGAATGACTA-3') and FMPl3b (5'-AGGTTGTATTAAA GTTTCGATCG-3') served as the internal control (Bilodeau et al. 2014; Miles et al. 2017). The Bandaid primer is an additional reverse primer used to increase the amplification sensitivity for $P$. cinnamomi isolates containing single-nucleotide polymorphisms in the reverse nad9 primer (PhyG-R6_Tail) (Miles et al. 2017). Amplification reactions were observed using TaqMan-based probes, including the Phytophthora genus-specific ATP9_PhyG2_probeR (5'-[Fam] AAAGCCATCATTAAACARAATAAAGC[BHQ1]-3'), Plant CAL-Red probe (5'-[CALFluorRed610]CTTTTATTATCACTTCC GGTACTGGCAGG[BHQ2]-3'), and P. cinnamomi Pcinn_nad9sp_ probe1 (5'-[Quasar670]AAGAAATATTTAGTTTATTAATATATA ATATAACT[BHQ2]-3') (Miles et al. 2017). TaqMan real-time PCR was performed in a CFX96 Real-Time PCR system (Bio-Rad Laboratories). Amplification reaction contained $12.5 \mu \mathrm{l}$ of $2.5 \times$ PerfeCTa Tough Mix (Quantabio, Beverly, MA), $3 \mu$ of $50 \mathrm{mM}$ $\mathrm{Mg}, 500 \mathrm{nM}$ each of the $\mathrm{nad} 9$ primers, $8 \mathrm{nM}$ Bandaid primer, $12.5 \mathrm{nM}$ each of cox primers, $50 \mathrm{nM}$ each of the Phytophthora probes, $10 \mathrm{nM}$ plant probe, and $1 \mu \mathrm{l}$ of the DNA template $(50 \mathrm{ng} / \mu \mathrm{l})$ in $25 \mu \mathrm{l}$ of total volume reaction. Thermal cycling consisted of $95^{\circ} \mathrm{C}$ for $2 \mathrm{~min}$ and 50 cycles at $95^{\circ} \mathrm{C}$ for $15 \mathrm{~s}$ and $57^{\circ} \mathrm{C}$ for $1 \mathrm{~min} 30 \mathrm{~s}$. Absolute quantification for the atp9-nad 9 marker data was calculated based on a serial dilution standard curve plot constructed using different known concentrations of DNA from $P$. cinnamomi isolate N-2113. Two technical replications were performed for each of the three biological replications for each time point.

Statistical analysis. Colony growth rate, fungicide sensitivity, lesion size in $N$. benthamiana, and TaqMan real-time PCR quantification results were analyzed using one-way analysis of variance (ANOVA) and the differences between means were compared using Fisher's least significant difference test. All these analyses were performed in $\mathrm{R}$ (version 3.1.3) (R Core Team 2015) using the agricolae package (Mendiburu 2015). Results were considered significant at $P \leq 0.05$. All assays had at least three replicates for each isolate and each experiment was repeated at least three times. Virulence test in avocado was analyzed using one-way randomeffects ANOVA and the differences between means were compared using Tukey's honestly significant difference test $(P \leq 0.05)$. These analyses were conducted using JMP Pro 13 software (SAS Institute Inc., Cary, NC). Five replicates were used for each rootstock and the experiment was repeated three times.

\section{RESULTS}

Effect of temperature on mycelial growth rate. Mycelial growth rates using cV8A nutrient media varied among isolates at 22,25 , and $28^{\circ} \mathrm{C}$ within and between groups (Table 1). None of the 12 isolates tested in this study differed significantly in colony morphology (data not shown). At $22^{\circ} \mathrm{C}$, all A2 clade I isolates collected from Northern California (Northern group) had significantly higher growth rates than isolates collected from Southern California (Southern group). The mycelial growth rate of the Northern group of isolates at this temperature ranged from $8.4 \pm$ 0.08 to $6.7 \pm 0.06 \mathrm{~mm} /$ day. In this group, $\mathrm{N}-2114$ had the highest growth rate among all isolates tested in this study at 22 and $25^{\circ} \mathrm{C}$ but

TABLE 1. Effect of temperature and nutrient media on mycelial growth of Phytophthora cinnamomi isolates on 10\% clarified V8 agar (cV8A) and corn meal agar (CMA)

\begin{tabular}{|c|c|c|c|c|c|}
\hline \multirow[b]{2}{*}{ Isolate } & \multirow[b]{2}{*}{ Clade } & \multicolumn{4}{|c|}{ Mycelial radial growth $(\mathrm{mm} / \text { day })^{\mathrm{y}}$} \\
\hline & & $22^{\circ} \mathrm{C}(\mathrm{CMA})$ & $22^{\circ} \mathrm{C}(\mathrm{cV} 8 \mathrm{~A})$ & $25^{\circ} \mathrm{C}(\mathrm{cV} 8 \mathrm{~A})$ & $28^{\circ} \mathrm{C}(\mathrm{cV} 8 \mathrm{~A})$ \\
\hline S-2109 & II & $5.13 \pm 0.07$ ef & $4.94 \pm 0.04 \mathrm{~g}$ & $4.56 \pm 0.06 \mathrm{fg}$ & $4.66 \pm 0.03 c$ \\
\hline S-2117 & II & $5.16 \pm 0.40 \mathrm{ef}$ & $5.59 \pm 0.27 \mathrm{f}$ & $5.28 \pm 0.38 \mathrm{e}$ & $5.09 \pm 0.26 b$ \\
\hline S-2120 & II & $5.38 \pm 0.09 \mathrm{e}$ & $5.88 \pm 0.05 \mathrm{f}$ & $5.66 \pm 0.11 \mathrm{e}$ & $5.50 \pm 0.11 \mathrm{a}$ \\
\hline S-2118 & II & $4.13 \pm 0.14 \mathrm{~g}$ & $4.47 \pm 0.12 \mathrm{~h}$ & $4.34 \pm 0.03 \mathrm{~g}$ & $4.72 \pm 0.06 \mathrm{c}$ \\
\hline S-st5b & Unknown ${ }^{\mathrm{z}}$ & $4.81 \pm 0.15 \mathrm{f}$ & $5.06 \pm 0.11 \mathrm{~g}$ & $4.84 \pm 0.06 \mathrm{f}$ & $4.63 \pm 0.05 c$ \\
\hline S-st6b & Unknown ${ }^{\mathrm{z}}$ & $4.75 \pm 0.05 \mathrm{f}$ & $4.63 \pm 0.05 \mathrm{gh}$ & $4.53 \pm 0.12 \mathrm{fg}$ & $4.66 \pm 0.09 \mathrm{c}$ \\
\hline $\mathrm{N}-2110$ & I & $5.97 \pm 0.08 \mathrm{~d}$ & $6.72 \pm 0.11 \mathrm{de}$ & $5.63 \pm 0.09 \mathrm{e}$ & $4.72 \pm 0.14 \mathrm{c}$ \\
\hline $\mathrm{N}-2113$ & I & $8.22 \pm 0.14 \mathrm{a}$ & $7.66 \pm 0.38 b$ & $7.66 \pm 0.09 \mathrm{~b}$ & $5.16 \pm 0.03 b$ \\
\hline $\mathrm{N}-2114$ & I & $7.97 \pm 0.14 \mathrm{ab}$ & $8.44 \pm 0.08 \mathrm{a}$ & $8.28 \pm 0.09 \mathrm{a}$ & $5.09 \pm 0.18 \mathrm{~b}$ \\
\hline N-B9 & I & $7.63 \pm 0.14 b c$ & $7.16 \pm 0.03 \mathrm{~cd}$ & $7.13 \pm 0.09 c$ & $5.13 \pm 0.05 b$ \\
\hline $\mathrm{N}-$ Vor10 & I & $6.06 \pm 0.08 \mathrm{~d}$ & $6.66 \pm 0.06 \mathrm{e}$ & $5.69 \pm 0.11 \mathrm{e}$ & $4.91 \pm 0.13 b c$ \\
\hline N-Van3 & I & $7.34 \pm 0.16 \mathrm{c}$ & $7.59 \pm 0.14 b c$ & $6.66 \pm 0.17 \mathrm{~d}$ & $4.94 \pm 0.04 b c$ \\
\hline
\end{tabular}

${ }^{y}$ Mean values \pm standard error. Numbers followed by the same letter do not differ significantly according to Fisher's least significance difference test at $P=0.05$.

$\mathrm{z}$ Isolates were collected from the same field as isolates 2109 and 2117 in 2010 but were not genotyped or included in the study by Pagliaccia et al. 2013. 
not at $28^{\circ} \mathrm{C}$, where the significant differences on growth rates among all isolates within and between groups were reduced (Table 1). The growth rate of the Southern isolates tested ranged from $4.5 \pm 0.12$ to $5.88 \pm 0.05 \mathrm{~mm} /$ day at $22^{\circ} \mathrm{C}$. Within this group, S-2117 and S-2120 exhibited the highest growth rates $(5.6 \pm 0.3$ and $5.9 \pm 0.05 \mathrm{~mm} /$ day, respectively) (Table 1) at all the temperatures tested.

The separation of the study isolates into two groups by mycelial growth rate was less evident as the temperature of incubation increased. Moreover, mycelial growth rates of the Northern group of isolates (A2 clade I) significantly decreased as temperature increased $(P<0.01)$, with means of $7.4 \pm 0.7,6.8 \pm 1$, and $4.99 \pm$ $0.1 \mathrm{~mm} /$ day at 22,25 , and $28^{\circ} \mathrm{C}$, respectively (Table 1 ). The mean of the growth rates of the Southern isolates $(5.1 \pm 0.5,4.9 \pm 0.5$, and $4.9 \pm 0.4 \mathrm{~mm} /$ day at 22,25 , and $28^{\circ} \mathrm{C}$, respectively) remained the same as incubation temperature increase $(P=0.143)$, suggesting that $P$. cinnamomi isolates collected from Northern California could be more sensitive to higher temperatures when compared with the isolates collected in Southern California. Together, these results suggest variability in mycelial growth rate and optimal growth temperatures among the isolates within and between these two groups of isolates.

Effect of nutrient media on colony growth rate. Mycelial growth rate was determined on two different nutrient media at $22^{\circ} \mathrm{C}$ to rule out the possibility that the differences observed within and between groups of isolates were due to the nutrient media composition. There was a significant effect of nutrient media on the mycelial growth of the isolates tested $(P=0.0142)$. However, all Northern A2 clade I isolates still showed higher mycelial growth rates than the Southern isolates when grown on $10 \% \mathrm{cV} 8 \mathrm{~A}$ or CMA media at $22^{\circ} \mathrm{C}$ (Table 1), suggesting that the correlation between mycelial growth rate and these two groups of isolates at this incubation temperature was not affected by nutrient media composition.

In vitro fungicide sensitivity. No isolates of $P$. cinnamomi tested in this study were insensitive to potassium phosphite, mefenoxam, fluopicolide, and oxathiapiprolin (Table 2). Potassium phosphite had the highest $\mathrm{EC}_{50}$ values for mycelial growth inhibition, with ranges and mean values of 19.3 to 34.1 and $24.3 \mu \mathrm{g} / \mathrm{ml}$ for the A2 clade I Northern isolates. On the other hand, higher $\mathrm{EC}_{50}$ values were found for all of the Southern isolates, ranging from 98.9 to $>100 \mu \mathrm{g} / \mathrm{ml}$, at least more than four times the mean for the Northern isolates. Oxathiapiprolin exhibited the lowest $\mathrm{EC}_{50}$ values, with ranges and mean values of 0.0002 to 0.0005 and $0.0003 \mu \mathrm{g} / \mathrm{ml}$ for all isolates. Mefenoxam and fluopicolide $\mathrm{EC}_{50}$ values ranged from 0.05 to 0.1 and 0.07 to $0.17 \mu \mathrm{g} / \mathrm{ml}$, respectively, among the isolates tested. These findings suggest that potassium phosphite sensitivity could be a group characteristic between $P$. cinnamomi isolates collected from Northern
California and isolates collected from Southern California. Moreover, in this study, we reported for the first time that $P$. cinnamomi avocado isolates from California are sensitive to fluopicolide and oxathiapiprolin, being the latest and most toxic among all four fungicides tested in this study.

$P$. cinnamomi virulence variability in avocado. To determine whether there are differences in virulence among representative isolates from Northern $(\mathrm{N}-2110, \mathrm{~N}-2113$, and N-2114) and Southern (S-2109, S-2117, and S-2120) populations from California, two avocado rootstock accessions with contrasting resistance phenotypes were inoculated using the six P. cinnamomi isolates individually and in mixtures. Dusa and PS.54, a moderately resistant and susceptible rootstock, respectively, were used. The percentage of healthy root tissue was significantly different $(\alpha=$ 0.05 ) between the Dusa and the PS.54 rootstock independent of the treatments. As expected, the root pathogen P. cinnamomi caused more disease in the roots of PS.54, the susceptible avocado rootstock, which exhibited less healthy root tissue (12.58\%) after infection compared with Dusa, the moderately resistant rootstock $(46.64 \%)$. Disease severities for each treatment as influenced by rootstock and isolate were compared. All isolates and their mixtures caused similar disease severity when a susceptible rootstock (PS.54) was used for inoculation (Fig. 1). However, two of the three Northern isolates $(\mathrm{N}-2110$ and N-2113) and the North mix appeared to cause less disease severity compared with the other treatments in this highly susceptible rootstock. On the other hand, when Dusa was used for pathogen inoculations, significant differences were detected among treatments (Fig. 1). For instance, the S-2109 and S-2117 Southern isolates were significantly more virulent than the $\mathrm{N}-2110$ and $\mathrm{N}-2113$ Northern isolates. The average of the percentage of healthy root tissue for the Southern isolates (27\%) was significantly different than the average of the Northern isolates $(57 \%)$ ( $t$ test, $P=0.02)$, suggesting that the Southern isolates were more virulent. Furthermore, the Northern and Southern groups of isolates were also differentiated by their virulence when inoculated in Dusa as mixtures (Fig. 1). The South mix (S2109, S-2117, and S-2120) caused significantly more disease severity than the Northern isolates when inoculated individually or as a mixture (North mix). Interestingly, no significant difference was found between the disease severity caused by the North mix and the mixture of all six isolates (All mix) (Fig. 1).

Development of $P$. cinnamomi detached-leaf inoculation assay using $N$. benthamiana. $P$. cinnamomi successfully infected and colonized $N$. benthamiana leaves exerting an expected hemibiotrophic lifestyle (Fig. 2). The infection process of the P. cinnamomi isolate N-2113 was followed visually over the course of $120 \mathrm{hpi}$. No visible signs of infection were observed from 3 to $36 \mathrm{hpi}$

TABLE 2. Fungicide effective concentrations at which $50 \%$ of the mycelial growth of the Phytophthora cinnamomi isolates tested in this study was inhibited (EC $\mathrm{E}_{50}$ values)

\begin{tabular}{|c|c|c|c|c|}
\hline \multirow[b]{2}{*}{ Isolate } & \multicolumn{3}{|c|}{ Fungicide $\mathrm{EC}_{50}(\mu \mathrm{g} / \mathrm{ml})^{\mathrm{x}}$} & \multirow[b]{2}{*}{ Fluopicolide } \\
\hline & Potassium phosphite ${ }^{y}$ & Mefenoxam ${ }^{z}$ & Oxathiapiprolin ${ }^{z}$ & \\
\hline S-2109 & $>100$ & $0.05502 \mathrm{~b}$ & $0.00028 \mathrm{~cd}$ & $0.12521 \mathrm{ab}$ \\
\hline S-2117 & $>100$ & $0.06127 \mathrm{ab}$ & 0.00018 ef & $0.10641 \mathrm{bc}$ \\
\hline S-2120 & $>100$ & $0.06811 \mathrm{ab}$ & $0.00016 \mathrm{f}$ & $0.09923 \mathrm{bc}$ \\
\hline S-2118 & $98.93 \mathrm{a}$ & $0.07086 \mathrm{ab}$ & $0.00029 \mathrm{bcd}$ & $0.09685 \mathrm{bc}$ \\
\hline S-st5b & $>100$ & $0.05003 \mathrm{~b}$ & 0.00022 def & $0.08901 \mathrm{bc}$ \\
\hline S-st6b & $>100$ & $0.05002 \mathrm{~b}$ & 0.00024 def & $0.10239 \mathrm{bc}$ \\
\hline N-2113 & $19.62 \mathrm{e}$ & $0.07148 \mathrm{ab}$ & $0.00044 \mathrm{a}$ & $0.13675 \mathrm{ab}$ \\
\hline N-2110 & $34.06 \mathrm{~b}$ & $0.09463 \mathrm{a}$ & $0.00038 \mathrm{ab}$ & $0.11455 \mathrm{bc}$ \\
\hline N-2114 & $24.24 \mathrm{~d}$ & $0.09540 \mathrm{a}$ & $0.00026 \mathrm{cde}$ & $0.16683 \mathrm{a}$ \\
\hline N-B9 & $19.25 \mathrm{e}$ & $0.07215 \mathrm{ab}$ & $0.00031 \mathrm{bcd}$ & $0.09090 \mathrm{bc}$ \\
\hline N-Vor10 & $28.53 \mathrm{c}$ & $0.04719 \mathrm{~b}$ & $0.00034 \mathrm{bc}$ & $0.07263 \mathrm{c}$ \\
\hline N-Van3 & $19.97 \mathrm{e}$ & $0.04283 \mathrm{~b}$ & $0.00045 \mathrm{a}$ & $0.13301 \mathrm{ab}$ \\
\hline
\end{tabular}

x Numbers followed by the same letter do not differ significantly according to Fisher's least significance difference test at $P=0.05$.

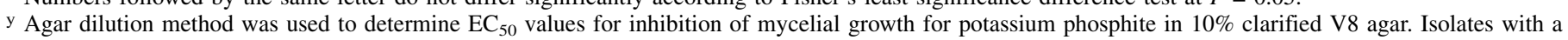
calculated $\mathrm{EC}_{50}>100 \mu \mathrm{g} / \mathrm{ml}$ (highest concentration tested) are designated $>100$.

z Spiral gradient dilution method was used to determine $\mathrm{EC}_{50}$ values for inhibition of mycelial growth for each fungicide tested in $10 \% \mathrm{cV} 8 \mathrm{~A}$. 
(Supplementary Fig. S1; Fig. 2A, B, and C) and in all of the mockinoculated leaves (data not shown). Necrotic lesions were observed at $48 \mathrm{hpi}$ and expanded until the last time point assessed (Fig. 2D, E, and F). By $120 \mathrm{hpi}$, the whole leaf was completely necrotized (data not shown).

At 3 hpi, most of the zoospores encysted but did not germinate, as revealed by trypan blue staining of the infected tissue. Germinated cysts and subjacent nascent hyphae were visible at 6 and 12 hpi (Fig. 2G). Pathogen colonization was observed from 24 to $36 \mathrm{hpi}$, with no microscopic signs of cell death (Fig. $2 \mathrm{H}$ and I). Pathogen haustoria were visible at 24 and 36 hpi (Fig. $2 \mathrm{H}$ and I), indicative of its biotrophic growth. Cell death was observed microscopically by trypan blue staining at 48 hpi (Fig. 2J); this was in agreement with the development of visible necrotic lesions at the inoculated area by this time point (Fig. 2D). Cell death expanded from the inoculated area until the last time point analyzed (Fig. $2 \mathrm{~K}$ and L).

Visible and microscopic observations were confirmed by $P$. cinnamomi DNA quantification in the infected tissue at each time point of inoculation analyzed using TaqMan real-time PCR (Fig. 3). P. cinnamomi (N-2113) DNA was used to generate the serial dilution standard curve plot (Fig. 3A) that was used to determine the amount of pathogen DNA in the inoculated area at each time point analyzed (Fig. 3B). In agreement with the macroscopic and microscopic assessment of the disease progression in $N$. benthamiana, $P$. cinnamomi DNA increased throughout the course of the infection process. Levels began to increase from 6 to $12 \mathrm{hpi}$ and continued to increase until $48 \mathrm{hpi}$. At $48 \mathrm{hpi}$, the total pathogen DNA no longer increased (Fig. 3B). Finally, this $P$. cinnamomi detached-leaf inoculation method was validated by detecting significant differences in virulence among $P$. cinnamomi S-2109 and N-2113 isolates, which exhibited contrasting virulence phenotypes in avocado using the traditional whole-plant root inoculation method in Dusa rootstocks (Fig. 1). Similarly, the most virulent isolate (S-2109) formed significantly larger necrotic lesions at 3 dpi when compared with the less virulent isolate, N-2113 (Supplementary Fig. S2).

\section{DISCUSSION}

This is the first study describing the phenotype of $P$. cinnamomi isolates, collected from PRR-infected avocado roots, representing the two A2 mating types groups (A2 clade I and II) identified by Pagliaccia et al. (2013). The A2 clade I contained P. cinnamomi isolates collected from 1989 to 2010, whereas the A2 clade II only contained a unique set of isolates collected in 2009 and 2010 from Southern California avocado-growing regions. This study reported significant differences in vegetative growth, fungicide sensitivity, and virulence among all of the isolates tested. Moreover, Southern isolates were less sensitive to potassium phosphite and had a slower growth rate at $22^{\circ} \mathrm{C}$, whereas Northern isolates were more sensitive to potassium phosphite and had higher growth rates. This observed trend suggests a correlation between mycelial growth rate at $22^{\circ} \mathrm{C}$ and potassium phosphite sensitivity with specific group of isolates.

The group of Northern isolates corresponding to the A2 clade I mating type group exhibited higher mycelial growth rates than the Southern group of isolates at $22^{\circ} \mathrm{C}$ independent of the nutrient media used (cV8A or CMA). Consistent with the results of Zentmyer et al. (1976), there was a significant effect of nutrient media and mycelial growth rate of the $P$. cinnamomi study isolates; however, this effect did not alter the split of the Northern and Southern isolates by their growth rate. The higher sensitivity of the A2 clade I isolates collected from Northern California to higher temperatures when compared with the Southern isolates might be explained by the fact that the median temperature is higher in Southern than in Northern California throughout the year.

Previous studies reported phenotypic differences in colony morphology, growth rate, and optimum growth temperature among
$P$. cinnamomi isolates; however, the majority of these studies compared isolates from different mating types, origins (countries), and host plants (Eggers et al. 2012; Phillips and Weste 1985; Zentmyer et al. 1976). Only a few studies have included $P$. cinnamomi associated with avocado when assessing phenotypic variability (Chee and Newhook 1965; López-Herrera and PérezJiménez 1995; Zentmyer et al. 1976; Zentmyer 1980). In the majority of these studies, the authors could not assign a phenotypic trait to a specific group of isolates. Others have reported varying results on the linkage between genotype groups and colony morphology. Dobrowolski et al. (2003) reported that colony morphology of Australian P. cinnamomi isolates grouped with a particularly genotype. In contrast to these results, colony morphology among the 12 isolates tested in this study did not vary significantly. LópezHerrera and Pérez-Jiménez (1995) reported significant differences in colony morphology among P. cinnamomi A2 isolates collected from avocado trees in Spain but these isolates did not exhibit significant differences on mycelial growth rates. California produces $95 \%$ of the avocado crop for the United States and PRR caused by $P$. cinnamomi is responsible for commercial losses totaling $\$ 40$ million annually statewide. Mefenoxam and phosphite applications are widely used to prevent and combat this disease (Darvas et al. 1984; Duan et al. 2008; Hardy et al. 2001; Hu et al. 2010; Ma and McLeod 2014; Pegg et al. 1985; Shearer and Fairman 2007); however, there is a notable preference for phosphite products over mefenoxam among the growers, and this is particularly true for California growers. This preference could explain why mefenoxam-resistant isolates were not found in this study. Moreover, the range of the $\mathrm{EC}_{50}$ values for mefenoxam was consistent with previous values reported for P. cinnamomi in the United States (Benson and Grand 2000; Duan et al. 2008; Hu et al. 2010). Duan et al. (2008) reported minor variation in sensitivity to mefenoxam among $P$. cinnamomi isolates collected from diseased ornamental plants in South Carolina. The $\mathrm{EC}_{50}$ values of the majority of these isolates were $<0.1 \mu \mathrm{g} / \mathrm{ml}$. Hu et al. (2010) found that there were more variations in mefenoxam sensitivity among $P$. cinnamomi isolates collected from different host species than from the same host. In this study, the authors classified isolates as sensitive to mefenoxam when their $\mathrm{EC}_{50}$ values ranged from 0.01 to $0.02 \mu \mathrm{g} / \mathrm{ml}$ and as intermediate when $\mathrm{EC}_{50}$ values ranged from 0.03 to 0.08

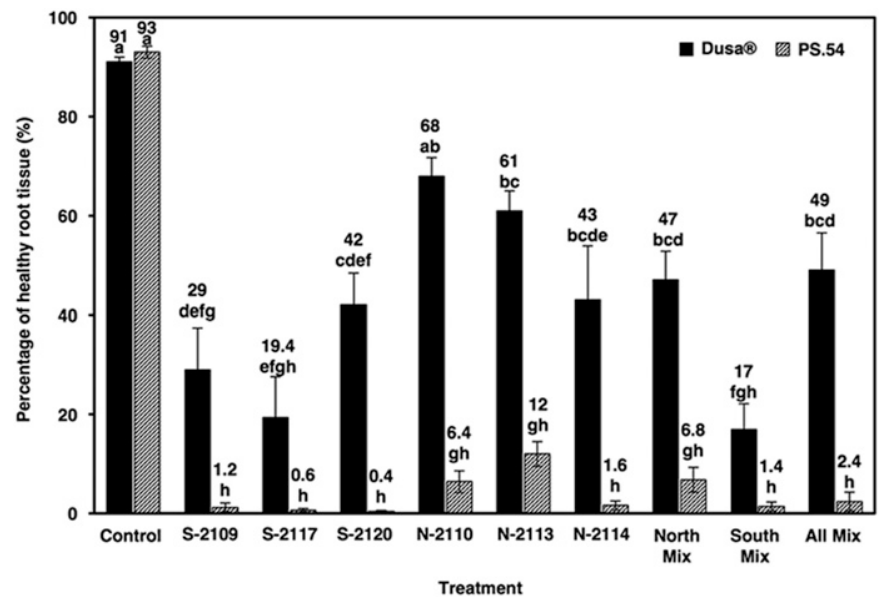

Fig. 1. Virulence test of Phytophthora cinnamomi isolates individually and in mixtures on moderately resistant (Dusa) and susceptible (PS.54) avocado rootstocks. Disease ratings were measured as percentage of healthy root tissue 17 weeks after inoculation. Disease severity was measured as percentage of healthy root tissue after pathogen root inoculation. More virulent isolates caused higher disease severity (less percentage of healthy root tissue). Error bars indicate standard errors of the means of five replicates. Means are indicated as numbers. Means with the same letter were not significantly different according to Tukey's honestly significant difference test. The experiment was repeated at least three times, with similar results. 
$\mu \mathrm{g} / \mathrm{ml}$. The $\mathrm{EC}_{50}$ values for mefenoxam in this study were also $<0.1 \mu \mathrm{g} / \mathrm{ml}$, suggesting that the repeated use of this fungicide to control PRR in nurseries and avocado orchards does not appear to have reduced the mefenoxam sensitivity of $P$. cinnamomi isolates.

In contrast to mefenoxam, we detected a significant variability among the isolates in potassium phosphite sensitivity but we did not find potassium phosphite-resistant isolates. The Northern isolates corresponding to the A2 clade I group had $\mathrm{EC}_{50}$ values $<34.1 \mu \mathrm{g} / \mathrm{ml}$, whereas the Southern isolates had $\mathrm{EC}_{50}$ values $>98.9 \mu \mathrm{g} / \mathrm{ml}$. It is worrisome that the Southern group of isolates, including the A2 clade II isolates that exhibited more virulence in the moderately resistant Dusa, which is the current industry standard rootstock
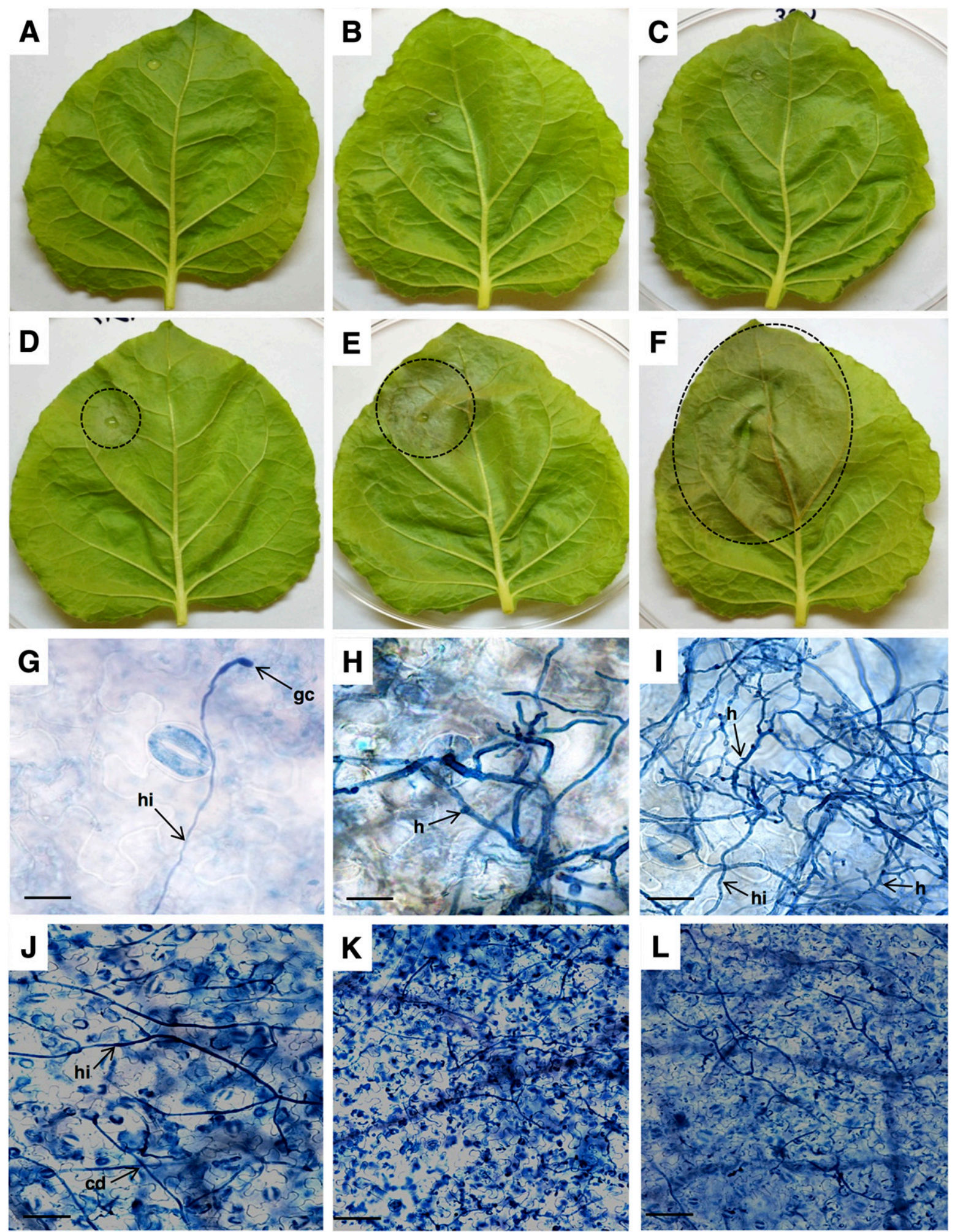

Fig. 2. Disease progression in Nicotiana benthamiana leaves inoculated with the N-2113 isolate of Phytophthora cinnamomi using a detached-leaflet assay. A to F, Photographs were taken at $12,24,36,48,72$, and $96 \mathrm{~h}$ postinoculation (hpi), respectively. Necrotic lesions are circled. Scale bar $=80 \mu \mathrm{m}$. G to $\mathbf{L}$, Light microscopy sections of leaves stained with trypan blue at 12,24,36, 48, 72, and $96 \mathrm{hpi}$, respectively. Scale bar $=20 \mu \mathrm{m}, \mathrm{gc}=$ germinated cyst, hi $=$ hyphae, $\mathrm{h}=\mathrm{haustoria}$, and $\mathrm{cd}=$ cell death. 
among California avocado growers, were less sensitive to potassium phosphite. Their higher $\mathrm{EC}_{50}$ values could represent a selection due to higher doses of potassium phosphite being necessary to suppress and control avocado root rot where these isolates are present. A more detailed study, with a larger number of isolates and history of phosphonate applications in the field, is needed to test this hypothesis. Dobrowolski et al. (2008) demonstrated that $P$. cinnamomi isolates exposed to long periods of phosphite treatment in avocado orchards in Australia exhibited reduced sensitivity to phosphite when evaluated on avocado, lupin, and eucalyptus, suggesting the onset of resistance to this fungicide. Similar results have been reported for $P$. cinnamomi isolates from avocado orchards in South Africa (Ma and McLeod 2014). This study reports, for the first time, the presence of $P$. cinnamomi isolates, collected from PRR-diseased avocado roots in California, that are less sensitive to potassium phosphite.

To help delay the development of phosphite-resistant $P$. cinnamomi isolates, care should be taken to alternate or mix phosphite products with other effective fungicides with different modes of action to control avocado PRR. Phosphite and mefenoxam rotation with alternative fungicides is commonly used to prevent or reduce the emergence of Phytophthora-resistant isolates (Saville et al. 2015); however, there are no other fungicides tested or registered to control $P$. cinnamomi in avocado. Fluopicolide and oxathiapiprolin are two new oomycete-targeted fungicides that have been tested for several Phytophthora spp. but not for P. cinnamomi (Keinath and Kousik 2011; Miao et al. 2016; Patel et al. 2015; Saville et al. 2015). In this study, we report, for the first time, that the $\mathrm{EC}_{50}$ values for mycelial growth inhibition of $P$. cinnamomi avocado isolates are within the range of the $\mathrm{EC}_{50}$ values reported for other Phytophthora spp. using these two fungicides (Gray et al. 2018; Keinath and Kousik 2011; Miao et al. 2016). Gray et al. (2018) recently reported the fluopicolide and oxathiapiprolin $\mathrm{EC}_{50}$ values for several Phytophthora spp. associated with citrus in California. Fluopicolide $\mathrm{EC}_{50}$ values for $P$. citrophthora, $P$. syringae, $P$. nicotianae, and $P$. hibernalis ranged from 0.031 to $0.087,0.02$ to $0.0461,0.039$ to 0.095 , and 0.017 to $0.018 \mu \mathrm{g} / \mathrm{ml}$, respectively.

Of the four fungicides evaluated in this study, oxathiapiprolin had the lowest $\mathrm{EC}_{50}$ values $(0.00016$ to $0.00045 \mu \mathrm{g} / \mathrm{ml})$. This range is similar to $\mathrm{EC}_{50}$ values reported for other Phytophthora spp. (Gray et al. 2018; Miao et al. 2016), including P. sojae, another member of the phylogenetic clade 7 , which includes $P$. cinnamomi (Martin et al. 2014). In agreement with our study, Gray et al. (2018), also found that this fungicide had the lowest $\mathrm{EC}_{50}$ values among five different fungicides tested. The authors reported oxathiapiprolin $\mathrm{EC}_{50}$ values for $P$. citrophthora, $P$. syringae, $P$. nicotianae, and $P$. hibernalis ranged from 0.0002 to $0.0015,0.0002$ to 0.0003 , 0.0003 to 0.001 , and $<0.0003 \mu \mathrm{g} / \mathrm{ml}$, respectively.

Interestingly, in contrast to potassium phosphite sensitivity, the Southern isolates in this study exhibited lower $\mathrm{EC}_{50}$ values than the Northern A2 clade I isolates. These results suggest the potential to rotate oxathiapiprolin with phosphonates and mefenoxam for controlling avocado PRR in California, reducing the risk of the emergence of phosphonate-resistant $P$. cinnamomi isolates.

Significant variations in pathogenicity and virulence among $P$. cinnamomi isolates collected from different host plants have been previously reported (Dudzinski et al. 1993; Linde et al. 1999; Robin et al. 1998; Zentmyer 1980; Zentmyer and Guillemet 1981). Few cases have reported no differences in virulence among $P$. cinnamomi isolates collected from different hosts (Podger 1989) and unique hosts, including one study in avocado (Eggers et al. 2012; Zentmyer 1980). In this study, we found significant differences in virulence among three representative $P$. cinnamomi isolates from the two A2 clonal groups identified by Pagliaccia et al. (2013) when we inoculated a moderately resistant avocado rootstock but not the most susceptible one. The use of highly susceptible plants to distinguish between isolates with different levels of virulence is challenging and could explain why we did not detect significant differences in virulence among our isolates when we used a susceptible avocado rootstock (PS.54). Although the mixture of the A2 clade II isolates (South mix) was more virulent than the mixture of the A2 clade I isolates (North mix), we observed that the mixture of all isolates together exhibited the same disease severity as the mixture of the less aggressive ones (Fig. 1). This observation might be explained by the level of competition between these two groups or might reflect the induction of specific plant defense responses triggered by these two distinct groups of isolates. A more comprehensive study is required to test these two possibilities.

Similar to this study, Linde et al. (1999), reported correlations between $P$. cinnamomi genotypes from Australia and South Africa and the level of virulence in eucalyptus, suggesting that genotype variation may indicate pathogenic variability. On the other hand, Eggers et al. (2012) did not detect differences in pathogenicity or virulence among $P$. cinnamomi isolates from oak forest soils in Eastern United States. Zentmyer (1980) did not find significant differences in pathogenicity among 12 A2 California isolates collected from avocado in Northern and Sothern California when inoculating roots of susceptible avocado seedlings.
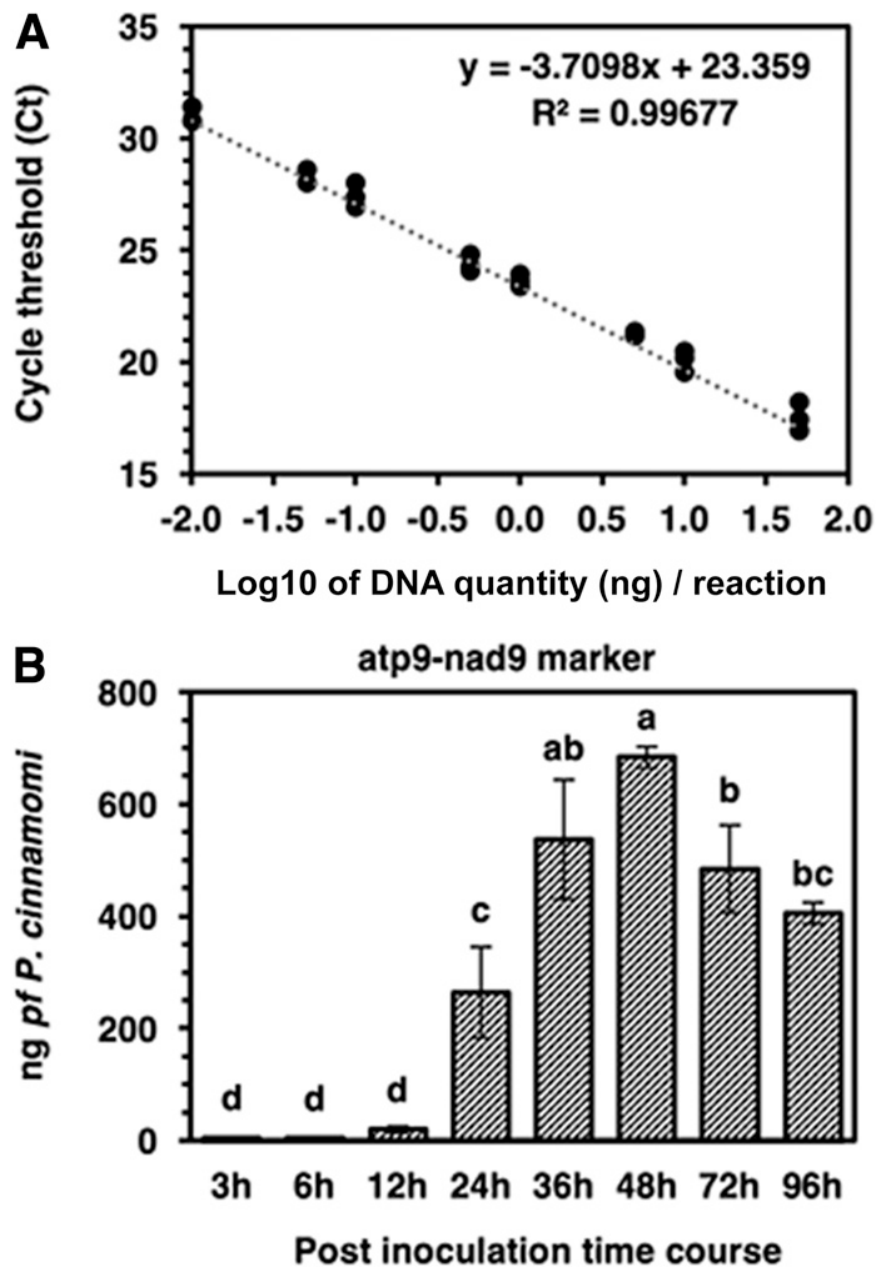

Fig. 3. Phytophthora cinnamomi DNA quantification in Nicotiana benthamiana leaves inoculated with N-2113 zoospores. A, Serial dilution standard curve plot generated using purified genomic DNA of isolate N-2113 of P. cinnamomi using the mitochondrial atp9-nad9 marker. Error bars indicate standard errors of the means of three technical replications. B, Quantification in nanograms (ng) using the mitochondrial atp9-nad9 marker. Error bars indicate standard error of the means of three biological replicates and two technical replications. Columns with the same letter indicate that isolate means were not significantly different $(P<0.05)$ following an analysis of variance and Fisher's least significance difference means separation procedures. 
P. cinnamomi isolates less sensitive to phosphite, and more virulent, exhibited a slower mycelial growth rate. Based on these results, we speculated that a negative correlation might exist between the in vitro growth rates of some $P$. cinnamomi isolates with the level of virulence and sensitivity to fungicides, which could potentially indicate a fitness cost for some traits over other acquired traits. Our results did not support the standard assumption that increased parasite growth leads to increased virulence (classical virulence evolution theory) (Alizon et al. 2009; Anderson and May 1982) but are consistent with an increasing amount of evidence for plant and human pathogens, indicating that there is a tradeoff between parasite growth and virulence and pathogen survival (Childers et al. 2015; Leggett et al. 2017; Meyer et al. 2010; Thrall et al. 2005). Childers et al. (2015) showed that many isolates of $P$. infestans (hemibiotrophic oomycete) that acquired resistance to mefenoxam exhibited retarded mycelial growth in comparison with the parental isolates that have never been exposed to this fungicide. More research is required to test some of these hypotheses. Similar to this study, Meyer et al. (2010) found that virulence of the necrotrophic fungal pathogen Pyrenophora semeniperda was significantly negatively correlated with mycelial growth, suggesting a tradeoff between these two traits, considering that the production of pathogen toxins necessary to kill the host cells competes with the metabolic processes required for pathogen growth. Similar tradeoff scenarios could be applied for hemibiotrophic pathogens such as Phytophthora cinnamomi because, at the beginning of the interaction with their host plants, hemibiotrophs need to produce effector proteins to avoid plant recognition and suppress the plant immune system at the biotrophic stages. Furthermore, later in the interaction, these pathogens need to switch to a necrotrophic stage involving the production of another sets of effector proteins to induce host cell death, including pathogen toxins (Fawke et al. 2015; Hardham and Blackman 2018).

Variability in pathogenicity and virulence among $P$. cinnamomi isolates has been tested using woody perennial crops such as avocado, eucalyptus, oak, and chestnut (Dudzinski et al. 1993; Linde et al. 1999; Robin et al. 1998; Zentmyer 1980). There are several limitations in using tree crops to study and characterize pathogenicity and virulence for a large number of $P$. cinnamomi isolates, including (i) the requirement for using genetically uniform clonal material, (ii) the fact that only a small number of experiments can be completed annually, (iii) the large greenhouse space required to conduct the experiments, and (iv) the long time (weeks) to score the disease.

Model plants, including Arabidopsis (Eshraghi et al. 2011; Robinson and Cahill 2003), Lupinus spp. (Eshraghi et al. 2014b; Gunning et al. 2013), and Medicago spp. (Huisman et al. 2015), have been previously reported as susceptible hosts for this oomycete pathogen and have been used to study $P$. cinnamomi pathogenesis and plant responses to this pathogen. $N$. benthamiana is a model plant that has been widely used by the oomycete community to understand Phytophthora pathogenicity (Kamoun et al. 1998) and the molecular interaction of pathogens with their host plants (Goodin et al. 2008). Recently, this model plant has been used to study other hemibiotrophic Phytophthora root pathogens such as P. palmivora (Evangelisti et al. 2017; Khunjan et al. 2016), P. capsici (Vega-Arreguín et al. 2014), and the citrus pathogen $P$. parasitica (Dalio et al. 2018). Taking advantage of the extremely wide host range of $P$. cinnamomi, we assessed and found that $P$. cinnamomi could infect and colonize $N$. benthamiana. Although P. cinnamomi has been reported on other Nicotiana spp. in Russia (Erwin and Ribeiro 1996), this study is the first report showing that $N$. benthamiana is also a host for this pathogen. Similar to the detached-leaf $P$. cinnamomi inoculation method developed in Arabidopsis, we used this detached-leaf assay to inoculate $N$. benthamiana leaves with this oomycete. Detached-leaf assays offer several advantages over whole-plant inoculations, including (i) greater reproducibility due to similar size and age of leaves, (ii) increased replication, (iii) more consisted delivery and localization of the inoculum in the leaves, (iv) uniform incubation conditions, (v) more accurate quantification of disease, and (vi) reduction of space require for inoculations. Robin and Guest (1994) used detached-leaf assays to characterize the pathogenicity of $P$. parasitica isolates in four tobacco cultivars. Detached-leaf assays have also been used in tree crops to study Phytophthora root pathogens' pathogenicity and virulence. Denman et al. (2005) used detached-leaf inoculations using different tree species to study the response of several isolates of $P$. ramorum. Helliwell et al. (2016) used detached-leaf assays using Theobroma cacao to study P. palmivora.

In agreement with previous studies using other host plants, including avocado, we found that $P$. cinnamomi, as expected, exhibited a hemibiotrophic lifestyle (Fawke et al. 2015; Hardham and Blackman 2018; Huisman et al. 2015; van den Berg et al. 2018) when inoculated on $N$. benthamiana leaves, as supported by our microscopic studies and DNA pathogen quantification using TaqMan real-time PCR. P. cinnamomi haustoria-like structures were detected in $N$. benthamiana leaves (Fig. 2H and I), as was found in infected roots of other host plants such as avocado (van den Berg et al. 2018), Medicago spp. (Huisman et al. 2015), and Quercus spp. (Redondo et al. 2015). Furthermore, the trend of $P$. cinnamomi growth in $N$. benthamiana leaves, determined by DNA quantification using TaqMan quantitative PCR, resembled the pathogen growth in avocado roots monitored using quantitative PCR (Miles et al. 2015). In avocadoinfected roots, $P$. cinnamomi continuously grew until $7 \mathrm{dpi}$; then, the pathogen growth decreased due to the complete necrosis of the avocado root system. Similarly, $P$. cinnamomi in $N$. benthamianainfected leaves continuously grew until $48 \mathrm{hpi}$, then decreased due to a complete necrosis of the inoculated area sampled for TaqMan DNA quantification (Figs. $2 \mathrm{E}$ and $\mathrm{F}$ and $3 \mathrm{~B}$ ). Finally, this $N$. benthamiana detached-leaf $P$. cinnamomi inoculation method was validated by successfully detecting significant differences in virulence between the S-2109 and the S-2113 isolates, which was consistent with our avocado inoculation results, indicating that this method could be used as an alternative inoculation method to circumvent the difficulties of using whole avocado root inoculation methods to assess the virulence of a large number of isolates. All of the experiments conducted in this work provide initial evidence of variability in growth rate, optimal growth temperature, fungicide sensitivity, and virulence among isolates representing the two A2 clonal populations identified by Pagliaccia et al. (2013). More importantly, the existence of $P$. cinnamomi isolates collected from PRR-diseased avocado roots that are more virulent and less sensitive to the current chemical control methods used by avocado growers in California will greatly influence the development of resistant avocado rootstocks and help the implementation of more effective cultural practices for managing avocado PRR in California, including, for example, the registration of new fungicides for avocado that can be used in combination with mefenoxam and phosphonates.

\section{ACKNOWLEDGMENTS}

We thank P. Mauk, A. Eskalen, and G. Xu as well as J. Mayorquin and N. Jackson (UCR) for their advisory role and technical assistance with some of the experiments conducted in this study; F. N. Martin (United States Department of Agriculture-Agricultural Research Service, Salinas CA) for providing Cn-2 P. cinnamomi DNA; Brokaw Nursery for donating some of the avocado rootstock liners used in this study; and W. E. Fry for critical reading of this manuscript prior to submission.

\section{LITERATURE CITED}

Adaskaveg, J. E., Hao, W., and Förster, H. 2015. Postharvest strategies for managing Phytophthora brown rot of citrus using potassium phosphite in combination with heat treatments. Plant Dis. 99:1477-1482. 
Alizon, S., Hurford, A., Mideo, N., and Van Ballen, M. 2009. Virulence evolution and the trade-off hypothesis: History, current state of affairs, and the future. J. Evol. Biol. 22:245-259.

Allardyce, J. A., Rookes, J. E., Hussain, H. I., and Cahill, D. M. 2013. Transcriptional profiling of Zea mays roots reveals roles for jasmonic acid and terpenoids in resistance against Phytophthora cinnamomi. Funct. Integr. Genomics 13:217-228.

Anderson, R. M., and May, R. M. 1982. Coevolution of hosts and parasites. Parasitology 85:411-426.

Andreassi, J. L., II, Gutteridge, S., Pember, S. O., and Sweigard, J. A. 2013. Detection and screening method and materials useful in performance thereof. International Patent No. WO2013009971. World Intellectual Property Organization.

Beaulieu, J., Ford, B., and Balci, Y. 2017. Genotypic diversity of Phytophthora cinnamomi and P. plurivora in Maryland's nurseries and Mid-Atlantic forests. Phytopathology 107:769-776.

Benson, D. M., and Grand, L. F. 2000. Incidence of Phytophthora root rot of Fraser fir in North Carolina and sensitivity of isolates of Phytophthora cinnamomi to metalaxyl. Plant Dis. 84:661-664.

Bilodeau, G. J., Martin, F. N., Coffey, M. D., and Blomquist, C. L. 2014. Development of a multiplex assay for genus- and species-specific detection of Phytophthora based on differences in mitochondrial gene order. Phytopathology 104:733-748.

Boesewinkel, H. J. 1976. Storage of fungal cultures in water. Trans. Br. Mycol. Soc. 66:183-185.

Bombarely, A., Rosli, H., Verbalov, J., Moffett, P., Mueller, L. A., and Martin, G. B. 2012. A draft genome sequence of Nicotiana benthamiana to enhance molecular plant-microbe biology research. Mol. Plant-Microbe Interact. 25: 1523-1530.

Briggs, G., Mansfield, D., Moloney, B., Gary, S., and Wegmann, T. 2006. The discovery and chemistry of fluopicolide: A new standard for oomycetes disease control. Pflanzenschutz Nachr. Bayer 59:141-152.

Brunner, I., Brodbeck, S., Büchler, U., and Sperisen, C. 2001. Molecular identification of fine roots of trees from the Alps: Reliable and fast DNA extraction and PCR-RFLP analyses of plastid DNA. Mol. Ecol. 10: 2079-2087.

Chee, K., and Newhook, F. 1965. Variability in Phytophthora cinnamomi Rands. N. Z. J. Agric. Res. 8:96-103.

Chen, D., and Zentmyer, G. A. 1970. Production of sporangia by Phytophthora cinnamomi in axenic culture. Mycologia 62:397-401.

Chen, X., Xing, Y., Li, Y., Tomg, Y., and Xu, J. 2013. RNA-Seq reveals infection-related gene expression changes in Phytophthora capsici. PLoS One 8:e74588.

Childers, R., Danies, G., Myers, K., Fei, Z., Small, I. M., and Fry, W. E. 2015. Acquired resistance to mefenoxam in sensitive isolates of Phytophthora infestans. Phytopathology 105:342-349.

Coffey, M. D., and Bower, L. A. 1984. In vitro variability among isolates of eight Phytophthora species in response to phosphorous acid. Phytopathology 74:738-742.

Dalio, R. J., Maximo, H. J., Oliveira, T. S., Dias, R. O., Breton, M. C., Felizatti, H., and Machado, M. 2018. Phytophthora parasitica effector PpRxLR2 suppresses Nicotiana benthamiana immunity. Mol. PlantMicrobe Interact. 31:481-493.

Darvas, J. M., Toerien, J. C., and Mine, D. L. 1984. Control of avocado root rot by trunk injection with phosethyl-Al. Plant Dis. 68:691-693.

Denman, S., Kirk, S. A., Brasier, C. M., and Webber, J. F. 2005. In vitro leaf inoculations studies as an indication of tree foliage susceptibility to Phytophthora ramorum in the UK. Plant Pathol. 54:512-521.

Dobrowolski, M. P., Shearer, B. L., Colquhoun, I. J., O’Brien, P. A., and Hardy, G. E. 2008. Selection for decreased sensitivity to phosphite in Phytophthora cinnamomi with prolonged use of fungicide. Plant Pathol. 57:928-936.

Dobrowolski, M. P., Tommerup, I. C., Shearer, B. L., and O'Brien, P. A. 2003. Three clonal lineage of Phytophthora cinnamomi in Australia revealed by microsatellites. Phytopathology 93:695-704.

Dong, L., Cheng, Y., Wu, J., Cheng, Q., Li, W., Fan, S., Jiang, L., Xu, Z., Kong, F., Zhang, D., Xu, P., and Zhang, S. 2015. Overexpression of GmERF5, a new member of the soybean EAR motif-containing ERF transcription factor, enhances resistance to Phytophthora sojae in soybean. J. Exp. Bot. 66:2635-2647

Drenth, A., and Sendall, B. 2001. Inoculation of soil. Pages 37-38 in: Practical Guide to Detection and Identification of Phytophthora. CRC for Tropical Plant Protection, Brisbane, Australia.

Duan, C. H., Riley, M. B., and Jeffers, S. N. 2008. Characterization of Phytophthora cinnamomi populations from ornamental plants in South Carolina, USA. Arch. Phytopathol. Plant Prot. 41:14-30.

Dudzinski, M. J., Old, K. M., and Gibbs, R. J. 1993. Pathogenic variability in Australian isolates of Phytophthora cinnamomi. Australas. J. Bot. 41: 721-732.
Eckert, J. W., and Tsao, P. H. 1962. A selective medium for isolation of Phytophthora and Pythium from plant roots. Phytopathology 52:771-777.

Eggers, J. E., Balci, Y., and MacDonald, W. L. 2012. Variation among Phytophthora cinnamomi isolates from oak forest soils in the eastern United States. Plant Dis. 96:1608-1614.

Ekchaweng, K., Evangelisti, E., Schornack, S., Tian, M., and Churngchow, N.2017. The plant defense and pathogen counterdefense mediated by Hevea brasilensis serine protease HbSPA and Phytophthora palmivora extracellular protease inhibitor PpEPI10. PLoS One 12:e0175795.

Engelbrecht, J., Duong, T. A., and Van der Berg, N. 2017. New microsatellite markers for population studies of Phytophthora cinnamomi, an important global pathogen. Sci. Rep. 7: Article 17631.

Erwin, D. C., and Ribeiro, O. K. 1996. Phytophthora Diseases Worldwide. The American Phytopathological Society Press, St. Paul, MN.

Eshraghi, L., Anderson, J. P., Aryamanesh, N., McComb, J. A., Shearer, B., and Hardy, G. E. St. J. 2014a. Defence signalling pathways involved in plant resistance and phosphite-mediated control of Phytophthora cinnamomi. Plant Mol. Biol. Rep. 32:342-356.

Eshraghi, L., Anderson, J. P., Aryamanesh, N., McComb, J. A., Shearer, B., and Hardy, G. E. St. J. 2014b. Suppression of the auxin response pathway enhances susceptibility to Phytophthora cinnamomi while phosphitemediated resistance stimulates the auxin signalling pathway. BMC Plant Biol. 14:68.

Eshraghi, L., Anderson, J., Aryamanesh, N., Shearer, B., McComb, J., Hardy, G. E. St. J., and O'Brien, P. A. 2011. Phosphite primed defense responses and enhanced expression of defense genes in Arabidopsis thaliana infected with Phytophthora cinnamomi. Plant Pathol. 60:1086-1095.

Evangelisti, E., Gogleva, A., Hainaux, T., Doumane, M., Tulin, F., Quan, C., and Schornack, S. 2017. Time-resolved dual transcriptomics reveal early induced Nicotiana benthamiana root genes and conserved infectionpromoting Phytophthora palmivora effectors. BMC Biol. 15:39.

Fawke, S., Doumane, M., and Schornack, S. 2015. Oomycete interactions with plants: Infection strategies and resistance principles. Microbiol. Mol. Biol. Rev. 79:263-280.

Fenn, M. E., and Coffey, M. D. 1984. Studies on the in vitro and in vivo antifungal activity of fosetyl-A1and phosphorous acid. Phytopathology 74: 606-611.

Förster, H., Kanetis, L., and Adaskaveg, J. E. 2004. Spiral gradient dilution, a rapid method for determining growth responses and $50 \%$ effective concentration values in fungus-fungicide interactions. Phytopathology 94:163-170.

Goodin, M. M., Zaitlin, D., Naidu, R. A., and Lommel, S. A. 2008. Nicotiana benthamiana: Its history and future as a model for plant-pathogen interactions. Mol. Plant-Microbe Interact. 21:1015-1026.

Gray, M., Hao, W., Förster, H., and Adaskaveg, J. E. 2018. Baseline sensitivities of new fungicides and their toxicity to selected life stages of Phytophthora species from citrus in California. Plant Dis. 102:734-742.

Guest, D., and Grant, B. R. 1991. The complex action of phosphonates as antifungal agents. Biol. Rev. 66:159-187.

Gunning, T. K., Conlan, X. A., Parker, R. M., Dyson, G. A., Adams, M. J., Barnett, N. W., and Cahill, D. M. 2013. Profiling of secondary metabolites in blue lupin inoculated with Phytophthora cinnamomi following phosphite treatment. Funct. Plant Biol. 40:1089-1097.

Hardham, A. R. 2005. Phytophthora cinnamomi. Mol. Plant Pathol. 6:589-604.

Hardham, A. R., and Blackman, L. M. 2018. Phytophthora cinnamomi. Mol. Plant Pathol. 19:260-285.

Hardy, G. E. St. J., Barrett, S., and Shearer, B. L. 2001. The future of phosphite as a fungicide to control the soilborne plant pathogen Phytophthora cinnamomi in natural ecosystems. Australas. Plant Pathol. 30:133-139.

Helliwell, E. E., Vega-Arreguín, J., Shi, Z., Bailey, B., Xiao, S., Maximova, S. N., Tyler, B. M., and Guiltinan, M. J. 2016. Enhanced resistance in Theobroma cacao against oomycete and fungal pathogens by secretion of phosphatidylinositol-3-phosphate-binding proteins. Plant Biotechnol. J. 14: 875-886.

Hu, J., Hong, C., Stromberg, E. L., and Moorman, G. W. 2010. Mefenoxam sensitivity in Phytophthora cinnamomi isolates. Plant Dis. 94:39-44.

Huisman, R., Bouwmeester, K., Brattinga, M., Govers, F., Bisseling, T., and Limpens, E. 2015. Haustorium formation in Medicago truncatula roots infected by Phytophthora palmivora does not involve the common endosymbiotic program shared by arbuscular mycorrhizal fungi and rhizobia. Mol. Plant-Microbe Interact. 28:1271-1280.

Kamoun, S., Furzer, O., Jones, J. D. G., Judelson, H. S., Ali, G. S., Dalio, R. J., Roy, S. G., Schena, L., Zambounis, A., Panabières, F., Cahill, D., Ruocco, M., Figueiredo, A., Chen, X. R., Hulvey, J., Stam, R., Lamour, K., Gijzen, M., Tyler, B. M., Grünwald, N. J., Mukhtar, M. S., Tomé, D. F., Tör, M., Van Den Ackerveken, G., McDowell, J., Daayf, F., Fry, W. E., Lindqvist-Kreuze, H., Meijer, H. J., Petre, B., Ristaino, J., Yoshida, K., Birch, P. R., and Govers, F. 2015. The top 10 oomycete pathogens in molecular plant pathology. Mol. Plant Pathol. 16:413-434. 
Kamoun, S., van West, P., Vleeshouwers, V., de Groot, K. E., and Govers, F. 1998. Resistance of Nicotiana benthamiana to Phytophthora infestans is mediated by the recognition of the elicitor protein INF1. Plant Cell 10: 1413-1426.

Keinath, A. P., and Kousik, C. S. 2011. Sensitivity of isolates of Phytophthora capsici from the eastern United States to fluopicolide. Plant Dis. 95: 1414-1419.

Khunjan, U., Ekchaweng, K., Panrat, T., Tian, M., and Churngchow, N. 2016. Molecular cloning of HbPR-1 gene from rubber tree, expression of HbPR-1 gene in Nicotiana benthamiana and its inhibition of Phytophthora palmivora. PLoS One 11:e0157591.

Kroon, L., Bakker, F., van den Bosch, G., Bonants, P., and Flier, W. 2004. Phylogenetic analysis of Phytophthora species based on mitochondrial and nuclear DNA sequences. Fungal Genet. Biol. 41:766-782.

Lamour, K. H., and Hausbeck, M. K. 2001. The dynamics of mefenoxam insensitivity in a recombining population of Phytophthora capsici characterized with amplified fragment length polymorphism markers. Phytopathology 91:553-557.

Leggett, H. C., Cornwallis, C. K., Buckling, A., and West, S. A. 2017. Growth rate, transmission mode and virulence in human pathogens. Philos. Trans. R. Soc. B. 372:20160094.

Linde, C., Drenth, A., Kemp, G. H., Wingfield, M. J., and von Bromembsen, S. L. 1997. Population structure of Phytophthora cinnamomi in South Africa. Phytopathology 87:822-827.

Linde, C., Kemp, G. H. J., and Wingfield, M. J. 1999. Variation in pathogenicity among South African isolates of Phytophthora cinnamomi. Eur. J. Plant Pathol. 105:231-239.

Londsdale, J. H., Botha, T., and Kotze, J. M. 1988. Preliminary trials to assess the resistance of three clonal avocado rootstocks to crown canker caused by Phytophthora cinnamomi. S. Afr. Avocado Grow. Assoc. Yearb. 11:35-37.

López-Herrera, C. J., and Pérez-Jiménez, R. M. 1995. Morphology of Phytophthora cinnamomi isolates from avocado orchards in the Coastal area of Southern Spain. J. Phytopathol. 143:735-737.

Ma, J., and McLeod, A. 2014. In vitro sensitivity of South African Phytophthora cinnamomi to phosphite at different phosphate concentrations. S. Afr. Avocado Grow. Assoc. Yearb. 37:79-84.

Manosalva, P., Manohar, M., von Reuss, S. H., Chen, S., Koch, A., Kaplan, F., Choe, A., Micikas, R. J., Wang, X., Kogel, K. H., Sternberg, P. W., Williamson, V. M., Schroeder, F. C., and Klessig, D. F. 2015. Conserved nematode signaling molecules elicit plant defenses and pathogen resistance. Nat. Commun. 6: Article 7795.

Martin, F. N., Blair, J. E., and Coffey, M. D. 2014. A combined mitochondrial and nuclear multilocus phylogeny of the genus Phytophthora. Fungal Genet. Biol. 66:19-32.

Martin, F. N., and Coffey, M. D. 2012. Mitochondrial haplotype analysis for differentiation of isolates of Phytophthora cinnamomi. Phytopathology 102:229-239.

McGrath, M. T. 2004. What are fungicides? Online publication. Plant Health Instruct. doi.org/10.1094/PHI-I-2004-0825-01

Mendiburu, F. 2015. agricolae: Statistical procedures for agricultural research. R Package Version 1.2-3. https://cran.r-project.org/package=agricolae

Meyer, S. E., Stewart, T. E., and Clement, S. 2010. The quick and the deadly: Growth vs. virulence in a seed bank pathogen. New Phytol. 187: 209-216.

Miao, J., Dong, X., Lin, D., Wang, Q., Liu, P., Chen, F., Du, Y., and Liu, X. 2016. Activity of the novel fungicide oxathiapiprolin against plantpathogenic oomycetes. Pest Manage. Sci. 72:1572-1577.

Miles, T. D., Martin, F. N., and Coffey, M. D. 2015. Development of rapid isothermal amplification assays for detection of Phytophthora spp. in plant tissue. Phytopathology 105:265-278.

Miles, T. D., Martin, F. N., Robideau, G., Bilodeau, G., and Coffey, M. D. 2017. Systematic development of Phytophthora species-specific mitochondrial diagnostic markers for economically important members of the genus. Plant Dis. 101:1162-1170.

Ouimette, D. G., and Coffey, M. D. 1989. Comparative antifungal activity of four phosphonate compounds against isolates of nine Phytophthora species. Phytopathology 79:761-767.

Pagliaccia, D., Pond, E., McKee, B., and Douhan, G. W. 2013. Population genetic structure of Phytophthora cinnamomi associated with avocado in California and the discovery of a potentially recent introduction of a new clonal lineage. Phytopathology 103:91-97.

Pasteris, R. J., Hanagan, M. A., Bisaha, J. J., Finkelstein, B. L., Hoffman, L. E., Gregory, V., Andreassi, J. L., Sweigard, J. A., Klyashchitsky, B. A., Henry, Y. T., and Berger, R. A. 2016. Discovery of oxathiapiprolin, a new oomycete fungicide that targets an oxysterol binding protein. Bioorg. Med. Chem. 24:354-361.
Patel, J. S., Costa de Novaes, M. I., and Zhang, S. 2015. Evaluation of the new compound oxathiapiprolin for control of downy mildew in basil. Plant Health Prog. 16:165-172.

Pegg, K. G., Whiley, A. W., Saranah, J. B., and Glass, R. J. 1985. Control of Phytophthora root rot of avocado with phosphorus acid. Australas. Plant Pathol. 14:25-29.

Phillips, D., and Weste, G. M. 1985. Growth rates of four Australian isolates of Phytophthora cinnamomi in relation to temperature. Trans. Br. Mycol. Soc. 84:183-185.

Pliego-Alfaro, F., and Litz, R. E. 2007. Biotechnology and avocado improvement. Calif. Avocado Soc. Yearb. 90:149-167.

Ploetz, R. C. 2013. Phytophthora root rot of Avocado. Pages 197-203 in: Phytophthora: A Global Perspective. CABI Plant Protection Series. K. Lamour, ed. CABI, England.

Podger, F. D. 1989. Comparative pathogenicity of fourteen Australian isolates of Phytophthora cinnamomi determined on transplants of Tasmanian temperate heathland. Aust. J. Bot. 37:491-500.

R Core Team 2015. R: A language and environment for statistical computing. $\mathrm{R}$ Foundation for Statistical Computing, Vienna, Austria. https://www. R-project.org.

Redondo, M., Pérez-Sierra, A., Abad-Campos, P., Torres, L., Solla, A., Reig-Armiñana, J., and García-Breijo, F. 2015. Histology of Quercus ilex roots during infection by Phytophthora cinnamomi. Trees (Berl.) 29:1943-1957.

Reitmann, A., Berger, D. K., and van den Berg, N. 2017. Putative pathogenicity genes of Phytophthora cinnamomi identified via RNA-Seq analysis of pre-infection structures. Eur. J. Plant Pathol. 147:211-228.

Robin, C., Desprez-Loustau, M. L., Capron, G., and Delatour, C. 1998. First record of Phytophthora cinnamomi on cork and holm oaks in France and evidence of pathogenicity. Ann. Sci. For. 55:869-883.

Robin, C., and Guest, D. 1994. Characterization of pathogenicity of Phytophthora parasitica isolates by stem and detached-leaf inoculations in four tobacco cultivars. N. Z. J. Crop Hortic. Sci. 22:159-166.

Robinson, L. H., and Cahill, D. M. 2003. Ecotypic variation in the response of Arabidopsis thaliana to Phytophthora cinnamomi. Australas. Plant Pathol. 32:53-64.

Rookes, J. E., Wright, M. L., and Cahill, D. M. 2008. Elucidation of defense responses and signaling pathways induced in Arabidopsis thaliana following challenge with Phytophthora cinnamomi. Physiol. Mol. Plant Pathol. 72:151-161.

Saville, A., Graham, K., Grünwald, N. J., Myers, K., Fry, W. E., and Ristaino, J. B. 2015. Fungicide sensitivity of US genotypes of Phytophthora infestans to six oomycete-targeted compounds. Plant Dis. 99:659-666.

Schwinn, F. J., and Staub, T. 1995. Oomycetes fungicides: Phenylamides and other fungicides against oomycetes. Pages 323-346 in: Modern Selective Fungicides, 2nd ed. H. Lyr, ed. Longman Scientific and Technical, Harlow, UK.

Shands, A. C., Yamagata, J. S., Wright, A. F., and Miles, T. D. 2016. First report of Phytophthora cinnamomi causing root rot of Southern highbush blueberry in California. Plant Dis. 100:537.

Shearer, B. L., and Fairman, R. G. 2007. A stem injection of phosphite protects Banksia species and Eucalyptus marginata from Phytophthora cinnamomi for at least four years. Australas. Plant Pathol. 36:78-86.

Shew, H. D. 1985. Response of Phytophthora parasitica var. nicotianae to metalaxyl exposure. Plant Dis. 69:559-562.

Staub, T. H., and Young, T. R. 1980. Fungitoxicity of metalaxyl against Phytophthora parasitica var. nicotianae. Phytopathology 70:797-801.

Thrall, P. H., Barrett, L. G., Burdon, J. J., and Alexander, H. M. 2005. Variation in pathogen aggressiveness within a metapopulation of the Cakile maritima-Alternaria brassicicola host-pathogen association. Plant Pathol. 54:265-274.

van den Berg, N., Christie, J. B., Aveling, T. A. S., and Engelbrecht, J. 2018. Callose and $\beta$-1-3 glucanase inhibit Phytophthora cinnamomi in a resistant avocado rootstock. Plant Pathol. 67:1150-1160.

Vega-Arreguín, J. C., Jalloh, A., Bos, J. I., and Moffett, P. 2014. Recognition of an Avr3a homologue plays a major role in mediating nonhost resistance to Phytophthora capsici in Nicotiana species. Mol. Plant-Microbe Interact. 27:770-780.

Zentmyer, G. A. 1980. Phytophthora cinnamomi and the Diseases it Causes. Monogr. No. 10. The American Phytopathological Society, St. Paul, MN.

Zentmyer, G. A. 1981. The effect of temperature on growth and pathogenesis of Phytophthora cinnamomi and on growth of its avocado host. Phytopathology 71:925-928.

Zentmyer, G. A., and Guillemet, F. B. 1981. Evidence for strains of Phytophthora cinnamomi. Plant Dis. 65:475-477.

Zentmyer, G. A., Leary, J. V., Klure, L. J., and Grantham, G. L. 1976. Variability in growth in Phytophthora cinnamomi in relation to temperature. Phytopathology 66:982-986.

Zentmyer, G. A., and Mircetich, S. M. 1966. Saprophytism and persistence in soil by Phytophthora cinnamomi. Phytopathology 56:710-712. 